\title{
Standardization of the Language Scale for School- Aged Children (LSSC)
}

\author{
YoonKyoung $\mathrm{Lee}^{\mathrm{a}}$, Hyunsook $\mathrm{Heo}^{\mathrm{b}}$, Seungmin Jang \\ ${ }^{a}$ Division of Speech Pathology and Audiology, Hallym University, Chuncheon, Korea \\ ${ }^{b}$ Department of Speech and Language Pathology, Graduate School of Public Health and Science, Hallym University, Chuncheon, Korea \\ 'Department of Psychology, Sungkyunkwan University, Seoul, Korea
}

\author{
Correspondence: YoonKyoung Lee, $\mathrm{PhD}$ \\ Division of Speech and Audiology, Hallym \\ University, 1 Hallymdaehak-gil, Chuncheon \\ 200-702, Korea \\ Tel: +82-33-248-2219 \\ Fax: $+82-33-256-3420$ \\ E-mail: ylee@hallym.ac.kr
}

Received: April 5, 2015

Revised: May 12, 2015

Accepted: May 28, 2015

\begin{abstract}
Objectives: While the number of school-aged children who need speech-language therapy has been increasing recently, standardized language tests for identifying those with language disorders are still limited. The present study aimed to develop a standardized language test for school-aged children, the Language Scale for School-aged Children (LSSC). Methods: The study was conducted as follows: composing subtests and developing items based on literature reviews, analyzing the validity of the test and discriminant and difficulty of items, revising the test through two preliminary examinations (1st N=178, 2nd N=182), and standardizing the test (LSSC) with 700 children samples. Results: The LSSC demonstrated high concurrent validity with the REVT-R/-E and high construct validity measured by the correlation of the language quotients of the LSSC and subtests. The reliability was measured by internal consistency, split-half, and test-retest methods which showed that the LSSC is highly reliable test. Conclusion: Results are discussed in terms of developing the procedures, and the validity and reliability of the test. The LSSC will be useful for identifying school-aged children with language disorders as well as for assessing the language ability of school-aged children.
\end{abstract}

Keywords: Language Scale for School-aged Children, LSSC, Standardized test, Reliability, Validity

언어장애 아동에 대한 언어치료는 언어문제를 갖는 아동들을 정확히 판별하는 것으로 시작된다. 아동의 언어문제는 표준화된 검사도구 이용이나 자발화 분석이나 행동 관찰, 부모 면담 등 여러 방법을 통해 확인할 수 있다. 그 중에서도 표준화된 검사도구를 이 용하는 방법은 검사도구나 절차가 마련되어 있어 상대적으로 활용 하기에 용이할 뿐만 아니라 제시된 규준이 아동의 수행을 비교집 단의 수행 내용과 비교할 수 있게 해주기 때문에 언어문제를 갖는 아동을 판별하는 데 유용하다(Lee, 2013). 때문에 잘 구성된 표준 화 검사를 개발하는 것은 무엇보다 중요한 일이라 하겠다.

표준화 검사를 개발할 때에는 우선적으로 평가하고자 하는 대 상과 평가 목적 및 내용을 고려하여야 한다. Paul (2007)은 아동언 어장애 판단을 위해서는 수용언어와 표현언어를 포함한 전반적인 언어 능력을 평가하는 언어검사를 사용하거나, 특정 영역만 평가 하는 도구를 사용할 때에는 두 가지 검사를 사용하도록 권장하였
다. 아동들에 따라서는 언어 양식이나 영역에 따라 수행에 유의한 차이를 보이는 경우가 있기 때문이다. 같은 맥락에서 Kim, Sung과 Lee (2003)도 언어장애의 여부를 판단하기 위한 검사들은 수용언 어와 표현언어는 물론 언어의 하위영역들을 고르게 포함될 수 있도 록 고려하여야 한다고 강조하였다.

또한 각 발달 시기마다 언어발달 양상이 다르며 검사하는 내용에 따라 검사 절차도 달라질 수 있으므로 검사의 항목들이 평가하고 자 하는 아동들의 발달적 특성을 잘 반영하는지와 평가 방법이 아 동들 수준에 적절한지도 고려되어야 한다. Lee (2007), Jin, Kown과 Lee (2008)는 학령기 언어발달에 대한 문헌 검토를 기반으로 학령 기에는 학령 전기에 비해 의미적 측면에서는 어휘의 양적 변화와 더불어 어휘들의 관계나 함축적인 표현들과 같은 질적 확장이 강조 되고, 문법적인 측면에서도 구나 절이 다양하게 포함된 복문 구조 의 비중이 커지는 것과 같은 발달적 차이를 보인다고 하였다. 또한 
주요 의사소통 환경이 가정에서 학교로 전환됨에 따라 이야기나 대화와 같은 담화적 영역이 더욱 중요한 의미를 갖게 되며, 언어 학 습과 관련이 큰 상위언어(matalinguistic) 능력이 중요해진다고 하 였다. 따라서 학령기 언어검사는 이러한 내용을 평가할 수 있도록 구성되어야 한다고 하였다.

표준화 검사는 무엇보다 검사의 타당도와 신뢰도를 갖추어야 한 다. 타당도란 검사가 실제로 측정하고자 하는 것을 측정하는가를 말하며, 신뢰도란 검사가 얼마나 일관되게 측정하는가를 말한다 (Haynes \& Pindzola, 2008; Sung, 1998). 검사의 타당도는 보통 구 인(construct) 타당도, 내용(content) 타당도, 준거(criterion) 타당도 로 측정되는데, Haynes와 Pindzola (2008)는 이 세 가지 타당도가 모두 보고되는 것이 좋다고 하였다. 특히 검사가 측정하고자 하는 개념을 평가할 수 있는 요인들로 잘 구성되어 있는가를 보여 주는 구인 타당도가 가장 중요하게 반영되어야 한다고 강조하였다. 구인 타당도는 요인분석과 같이 통계적으로 검증하기도 하나, 이론적 토 대를 탄탄히 하는 것도 한 방법이라 하겠다. 신뢰도도 타당도와 마 찬가지로 검사자간 신뢰도나 재검사 신뢰도, 반분검사 신뢰도 등 여러 방법으로 측정될 수 있다. 검사 문항을 충분히 하고, 검사의 절 차나 채점 방식을 체계적이고 조작적으로 잘 정의하는 것 등은 검 사의 신뢰도를 높이는 방법이 된다(Maxwell \& Satake, 2006).

검사의 타당도 및 신뢰도와 더불어 규준의 대표성 역시 검사 개 발에서 중요하게 고려해야 한다(Maxwell \& Satake, 2006). 검사가 타당도와 신뢰도를 갖추었다고 해도 규준의 대표성이 부족하다면 검사 결과를 신뢰롭게 받아들이기 어렵다. 검사의 대표성을 높이 기 위해서는 먼저 표본의 수가 충분한가를 고려할 수 있다. 몇몇 예 외는 있을 수 있으나 표본의 크기가 클수록 대표성이 커질 것이다. 하지만 표본의 크기가 크더라도 편향되어 있는 표본이라면 대표성 은 작아질 것이다. 따라서 대표성 있는 규준을 마련하기 위해서는 표본의 크기와 편향성을 모두 고려하는 것이 필요하다.

미국에서는 학령기 아동들을 대상으로 표준화된 검사들이 많 이 있으나, 그중에서 Test of Language Development-Intermediate fourth edition (TOLD-4; Newcomer \& Hammill, 2008)나 Clinical Evaluation of Language Fundamentals-5 (CELF-5; Wiig, Semel, \& Secord, 2013), 또는 Woodcock Language Proficiency Battery-Revised (WLPB-R; Woodcock, 1991) 등은 여러 하위 검사들로 구성 되어 전반적인 언어능력을 보고할 뿐 아니라, 수용언어나 표현언어 와 같은 언어 양식이나 의미, 문법, 화용, 담화 등과 같이 언어 영역 별 수행 결과를 제시해 준다. 특히 TOLD-4나 CELF-5는 여러 번의 검사 개정 과정을 통해 검사의 신뢰도와 타당도, 대표성을 높이고 자 노력하였다. 반면, 우리나라의 경우는 학령기 언어장애 아동들
을 대상으로 표준화된 언어검사로 '수용·표현 어휘력 검사(REVT)' (Kim, Hong, Kim, Jang, \& Lee, 2009)와 '구문의미이해력검사'(Pae, Lim, Lee, \& Chang, 2004), '언어문제해결력검사'(Pae, Lim, \& Lee, 2000)가 있으나 각 검사들이 어휘력이나 문장 이해력과 같은 제한 된 언어 영역이나 수용 언어와 같이 제한된 양식만을 평가하기 때 문에 학령기 아동들의 언어능력을 전반적으로 평가하는 데에는 제 한점이 있다(Lee, 2007).

최근 교육 및 임상 현장에서 학령기 언어장애 아동들이 점차 증 가하고 있으며 이들에 대한 평가 및 치료교육 프로그램에 대한 요 구도 높아지고 있다(Lee, 2006). 그러나 아직 학령기에 있는 우리나 라 아동들을 대상으로 언어 전반적인 능력을 평가하도록 개발된 검사가 없어서 언어치료 서비스가 필요한 학령기 언어장애 아동을 판별하는 데 어려움이 있으며, 이들을 위한 중재를 결정하는 데에 도 어려움이 있다. 본 연구는 이러한 배경 하에 학령기 아동의 전반 적인 언어능력을 평가할 수 있으며 신뢰도와 타당도를 갖춘 표준화 언어검사를 개발하고자 하였다.

\section{연구 방법}

학령기 아동 언어검사(Language Scale for School-aged Children, LSSC) 개발 및 표준화 연구는 (1) 검사 구성 및 문항 개발, (2) 2 차에 걸친 예비검사 및 검사 수정, (3) 표준화 검사 및 규준 마련의 3 단계 를 통해 진행되었다. 연구 진행 절차는 Figure 1에 요약하였다.

\section{1차 검사 구성 및 문항 개발}

학령기 언어발달자료와 현재 미국에서 사용되고 있는 언어검사 인 CELF-4 (Semel, Wiig, \& Secord, 2003), TOLD-I의 초판본과 4 판(Hammill \& Newcomer, 1982; Newcomer \& Hammill, 2008), WLPB-R (Woodcock, 1991) 검사를 참조하여 의미영역에서 상위 어 표현하기, 동의어·반의어 말하기, 문법영역에서 문법오류 판단 하기, 복문만들기, 화용영역에서 단락 듣고 이해하기의 총 6 개 하위 검사로 구성된 검사를 개발하였다.

각 하위검사별로 문항 수를 결정하고, 최종 검사문항의 약 1.21.5 배수의 문항을 개발하였다. 문항을 개발할 때에는 '표준국어문 법론'(Ko \& Nam, 2005)과 1학년부터 6학년까지의 2006학년도판 초등학교 국어 교과서, 초등학교 어휘연구들(Korea Ministry of Culture and Tourism, 1999; Lee, 1989; Lee, 1994; Park, 2003)을 참 조하여 학교 문법과 초등학교 교육과정에서 사용되는 언어표현들 을 최대한 반영하였다.

문헌연구를 통해 개발된 검사에 대해서 아동언어발달장애 또는 


\begin{tabular}{|c|c|c|}
\hline Constructing test and developing items & $\leftarrow$ & $\begin{array}{l}\text { - Constructing test and developing items based on standardized language tests for school-aged children, } \\
\text { Korean language text books for elementary school children, studies on language development of } \\
\text { school-aged children, books for school-aged children, etc. }\end{array}$ \\
\hline 乃 & \multirow{3}{*}{$\leftarrow$} & \\
\hline Measuring content validity & & - Measuring content validity with 3 SLPs who have doctoral degrees in speech and language pathology \\
\hline 马 & & \\
\hline 1st pilot study & $\leftarrow$ & $\begin{array}{l}\text { - Participants: } 178 \text { school-aged children } \\
\text { - Estimating item's difficulty and discriminant value using BayesiAn program } \\
\text { - Estimating preliminary reliability and validity of the test }\end{array}$ \\
\hline \multicolumn{3}{|r|}{ e } \\
\hline Test revision & $\leftarrow$ & $\begin{array}{l}\text { - Excluding low discriminant items } \\
\text { - Revision } 2 \text { subtests: expression superordinate } \rightarrow \text { superordinate comprehension and expression } \\
\text { - Supplementing } 3 \text { subtests: sentence comprehension, figurative sentence comprehension, sentence } \\
\text { repetition }\end{array}$ \\
\hline \multicolumn{3}{|l|}{ 乃 } \\
\hline 2nd pilot study & \multirow[t]{2}{*}{$\leftarrow$} & $\begin{array}{l}\text { - Participants: } 182 \text { school-aged children } \\
\text { - Item analysis on supplemented subtests using BayesiAn program }\end{array}$ \\
\hline \multicolumn{2}{|l|}{ Љ } & \\
\hline Determining the final version of the LSSC & \multirow[t]{2}{*}{$\leftarrow$} & $\begin{array}{l}\text { - Selecting and arranging items of revised subtests based on discriminants and difficulties } \\
\text { - Determining final version of the LSSC }\end{array}$ \\
\hline \multicolumn{2}{|c|}{ e } & \\
\hline Standardizing the LSSC & $\leftarrow$ & $\begin{array}{l}\text { - Participants: } 700 \text { school-aged children (106-128 children in each grade) } \\
\text { - Analyzing reliability and validity of the LSSC } \\
\text { - Statistical analysis for constructing norms }\end{array}$ \\
\hline
\end{tabular}

Figure 1. Developing procedure of Language Scale for School-age Children (LSSC). SLP= speech-language pathologist.

언어발달 분야 박사학위를 지니고 있으면서 현재 대학에서 학령기 언어장애를 강의하고 있거나 학령기 언어장애를 대상으로 5년 이 상의 임상경험을 지니고 있는 전문가 2인을 대상으로 (1) 검사를 구 성하는 하위검사의 적절성, (2) 하위검사를 구성하는 문항들의 적 절성의 두 부분으로 나누어 내용 타당도를 평가하게 하였으며 5점 척도(1점 '매우 타당하지 않다', 2점 '타당하지 않다', 3점 '보통이다', 4점 '타당하다', 5점 '매우 타당하다)에서 평균 4.2점으로 평가되었 다. 검사구성과 문항에서 3 점 이하로 평가된 내용에 대해 자문을 통해 수정 보완하였다.

\section{1차 예비검사 실시 및 검사 수정}

\section{연구 대상 및 자료수집 절차}

1 차 예비검사는 서울, 경기, 강원 지역의 초등학교 5 곳과 종합복 지관 5 곳에서 표집한 초등학교 1학년부터 6학년 178 명의 아동들을 대상으로 하였다. 대상아동들은 부모나 교사로부터 언어발달은 물 론 인지나 사회성, 운동기능 등의 발달에 문제가 없었다고 보고된 아동들로 K-WISC-III (Kwak, Park, \& Kim, 2001) 언어성 지능검사 를 실시하여 언어성지능지수가 평균(IQ 80) 이상 범위에 속하였다.

검사자는 대학원 및 대학교에서 언어병리학을 전공하는 학생 중 에서, 언어평가 및 치료 실습 과목을 이수하여 아동 언어평가 경험 이 있는 학생으로 선정하였다. 검사자들에게는 검사 실시 전에 검
사의 내용과 실시 절차에 대해 사전 교육을 실시하여 검사를 정확 하게 실시할 수 있도록 훈련하였다.

검사 장소는 각 초등학교 및 복지관 등 아동이 교육받는 장소에 서 상담실이나 과학실, 또는 방과 후의 빈 교실 등을 이용하였으며, 모든 아동에게 개별적으로 검사를 실시하였다. K-WISC-III의 언어 성 검사와 학령기 언어검사(LSSC 초판본)는 각 아동에게 무작위 적 순서로 실시하였다. 총 2 시간이 넘는 검사 소요시간으로 인하여 아동이 피로를 느낄 수 있으므로 가급적이면 2회에 나누어 검사를 실시하고자 하였으나, 시간이나 장소적 제약이 있는 경우에는 하루 에 검사를 마치도록 하였다. 하루에 검사를 마치는 경우는 검사 사 이에 휴식 시간을 주어 장시간의 검사로 인해 피로가 검사수행에 미치는 영향을 최소화하였다. 검사결과는 검사를 실시하는 즉시 그 자리에서 기록하였으며, 검사 후 일주일 이내에 채점하였다.

\section{검사 결과}

예비검사에서 측정한 자료는 BayesiAn (Sung, 2001)을 사용하 여 문항의 난이도와 변별도를 측정하였으며, 변별도 지수가 -.34 이 하여서 변별도가 없는 문항을 제외한 후 난이도에 따라 문항을 재 배열하였다. 이 과정에서 상위어 표현은 5 개 문항, 반의어와 동의어 표현은 각각 8 개 문항, 문법오류판단은 5 개 문항, 복문산출은 19 개 문항, 단락듣기이해는 3 개 문항을 제외하였다. 
문항분석을 통해 최종 결정된 검사에 대해 하위검사 간 상관분 석을 통해 구인타당도를 측정하였으며, K-WISC-III 언어성검사 공 인타당도를 측정하였다. 또한 Chronbach $\alpha$ 를 통해 신뢰도를 측정 한 결과, 문법판단을 제외한 모든 하위검사가 전체점수와 $r=.80$ 이 상으로 매우높은상관을 보여 높은 구인타당도를 보였으며, K-WISC$\mathrm{III}$ 언어성 전체점수가 LSSC의 총점과 $r=.909$, 다른 하위검사와도 $r=.70$ 이상으로 높은 공인타당도를 보였다. 또한 Chronbach $\alpha$ 로 측정한 문항내적일치도는 전체점수는 .98 , 하위검사도 모두 .80 이 상으로 높은 신뢰도를 나타냈다(Lee, 2007).

\section{검사 수정 보완}

1 차 예비검사를 통해서 개발된 검사가 전반적으로 표현언어 검 사 중심으로 구성되었다는 평가에 기반하여 각 언어영역별로 수용 과 표현이 고르게 평가될 수 있도록 검사를 수정하였다. 의미영역 에서 상위어 표현 검사를 상위개념 이해와 상위어 표현 두 개의 하 위 검사로 구분하였으며, 함축적 표현 이해를 목적으로 비유문 이 해 검사를 추가하였다. 문법영역에서는 문법오류 판단 검사를 문법 오류 판단과 수정의 두 개 검사로 구분하였으며, 구문 이해 검사를 추가하였다. 그리고 보조검사로 청각적 기억력을 측정하기 위해 문 장 따라말하기 검사를 추가하였다.

새로 추가한 검사에서 비유문 이해 검사의 문항은 2006년도판 초등학교 국어교과서와 초등학생용 속담 자료집 등을 참조하여 구 성하였으며, 구문 이해 검사는 Ha와 Lee (2006)에서 개발된 검사 를 수정 보완하여 추가하였다. 또한 문장 따라말하기 검사는 Lee (2007)에서 사용한 검사를 수정하여 포함하였다.

추가된 검사 중에서 그림자료를 활용하여 검사하는 비유문과 구문 이해 검사의 경우, 사용한 그림이 문항을 적절히 묘사하는가 를 언어병리학을 전공하는 대학원생 5 명에게 1 차 점검하게 하였으 며, 1-6학년 학생을 학년별로 2명씩 총 12명을 대상으로 그림을 검 토하게 하여 표현이 애매하다고 반응한 경우는 수정하는 절차를 거쳤다.

\section{2차 예비검사 실시 및 최종 검사 확정}

연구 대상 및 자료수집 절차

2 차 예비검사는 강원 춘천과 부산, 대구 지역 아동을 학년별로 30-31명씩 총 182명으로, 부모나 교사로부터 언어발달은 물론 인지 나 사회성, 운동기능 등의 발달에 문제가 없었다고 보고된 아동을 대상으로 하였다. 검사자 선정 및 훈련은 1 차 예비검사와 마찬가지 로 언어병리학을 전공하는 대학원생 및 학부생 중에서, 언어평가 및 치료 실습 과목을 이수하여 아동 언어평가 경험이 있는 학생을
선정하였으며, 검사의 내용과 실시 절차에 대해 사전 교육을 실시 하여 검사를 정확하게 실시할 수 있도록 훈련하였다. 검사 장소는 각 초등학교 및 복지관 등 아동이 교육받는 장소에서 상담실이나 과학실, 또는 방과 후의 빈 교실 등을 이용하였으며, 검사자와 아동 이 일대일로 검사를 실시하였다. 검사결과는 검사를 실시하는 즉 시 그 자리에서 기록하였으며, 검사 후 일주일 이내에 채점하였다.

\section{검사 결과}

2차 예비검사에서 측정한 자료 역시 BayesiAn (Sung, 2001)을 사 용하여 문항분석을 실시하였으며, 1 차 예비검사에서와 마찬가지로 변별도가 낮은 문항은 제외하였다. 이 과정을 통해 비유문 이해 검사 에서 7 개 문항과 문장 따라말하기 검사에서 9 개 문항을 제외하였다.

추가 된 5 개의 하위검사에 대해 1 차 예비검사를 통해 개발된 검사 들과의 상관분석을 통해 공인타당도를 측정한 결과 상위개념 이해 검사는 .607-.755, 구문 이해 검사는 .559-.625, 비유문 이해는 .504.691, 문법오류 수정하기는 문장 따라말하기는 .588-.685로 모두 $p<.001$ 수준에서 유의한 상관을 나타내 공인타당도가 높은 것으 로 나타났다. 또한 Chronbach $\alpha$ 로 측정한 문항내적일치도는 .857.882 로 높은 신뢰도를 보였다.

1,2 차 예비검사를 통해 최종적으로 결정된 검사의 구성 및 내용 은 Appendix 1과 같다.

\section{표준화 검사 실시}

\section{표본 추출}

LSSC의 표본은 초등학교 1학년에서 6학년에 재학중인 아동을 대상으로 전국적으로 표집하였다. 아동 표집 시 전국을 서울, 경상 (부산, 대구광역시 포함), 전라(광주광역시 포함), 충청, 강원·경기 의 5 대 권역으로 구분하였으며, 각 지역별 아동 분포를 고려하여 군 집표집과 편의표집 방법을 사용하여 표집하였다. 학년별 100 명을 목표로 하였으나, 각 학년에서 6-28명 정도 초과 표집되어 총 대상 아동은 700 명이었다. 최대한 학년별 지역 분포를 고르게 하려고 하 였으나 완전하게 일치시키지는 못하였으며, 학년과 지역분포 외의 성별은 통제하지 못하였다. 표집 시 각 지역별로 두 군데 이상에서 표집될 수 있도록 하였으며, 한 곳만 표집된 경우에는 다른 곳에 거 주하는 아동을 개별적으로 표집하여 가능한 여러 지역의 아동이 포함되도록 하였다. 또한 사회 경제적 수준이 각 지역의 중간 정도 에 해당되는 지역을 섭외하도록 고려하였으나, 사회 경제적 자료를 수집하지 못한 경우가 있어 완전하게 통제하지는 못하였다. 표준화 검사에 포함된 대상 아동의 학년별 분포는 Table 1 과 같다. 
Table 1. Distribution of samples by grade and geographical region

\begin{tabular}{|c|c|c|c|c|c|c|c|}
\hline & & Seoul & Kyungsang & Jeolla & Chungcheong & Gangwon/Gyunggi & Total \\
\hline 1 st grade & $\begin{array}{l}\mathrm{N} \\
\% \text { in grade } \\
\% \text { in total }\end{array}$ & $\begin{array}{r}28 \\
25.7 \\
4.0\end{array}$ & $\begin{array}{l}20 \\
18.3 \\
2.9\end{array}$ & $\begin{array}{l}10 \\
9.2 \\
1.4\end{array}$ & $\begin{array}{l}6 \\
5.5 \\
0.9\end{array}$ & \begin{tabular}{r}
\multicolumn{1}{c}{45} \\
41.3 \\
6.4
\end{tabular} & $\begin{array}{l}110 \\
100.0 \\
15.6\end{array}$ \\
\hline 2nd grade & $\begin{array}{l}\mathrm{N} \\
\% \text { in grade } \\
\% \text { in total }\end{array}$ & \begin{tabular}{r}
\multicolumn{1}{c}{39} \\
35.5 \\
5.6
\end{tabular} & $\begin{array}{r}28 \\
25.5 \\
4.0\end{array}$ & $\begin{array}{l}7 \\
6.4 \\
1.0\end{array}$ & $\begin{array}{l}13 \\
11.8 \\
1.9\end{array}$ & $\begin{array}{r}23 \\
20.9 \\
3.3\end{array}$ & $\begin{array}{l}109 \\
100.0 \\
15.7\end{array}$ \\
\hline 3rd grade & $\begin{array}{l}\mathrm{N} \\
\% \text { in grade } \\
\% \text { in total }\end{array}$ & $\begin{array}{r}35 \\
28.5 \\
5.0\end{array}$ & $\begin{array}{l}23 \\
18.7 \\
3.3\end{array}$ & $\begin{array}{c}12 \\
9.8 \\
1.7\end{array}$ & $\begin{array}{l}14 \\
11.4 \\
2.0\end{array}$ & $\begin{array}{r}39 \\
31.7 \\
5.6\end{array}$ & $\begin{array}{l}123 \\
100.0 \\
17.6\end{array}$ \\
\hline 4th grade & $\begin{array}{l}\mathrm{N} \\
\% \text { in grade } \\
\% \text { in total }\end{array}$ & $\begin{array}{l}46 \\
37.1 \\
6.6\end{array}$ & $\begin{array}{l}15 \\
12.1 \\
2.1\end{array}$ & $\begin{array}{l}11 \\
8.9 \\
1.6\end{array}$ & $\begin{array}{l}20 \\
16.1 \\
2.9\end{array}$ & \begin{tabular}{r}
\multicolumn{1}{c}{32} \\
25.8 \\
4.6
\end{tabular} & $\begin{array}{l}124 \\
100.0 \\
17.7\end{array}$ \\
\hline 5th grade & $\begin{array}{l}\mathrm{N} \\
\% \text { in grade } \\
\% \text { in total }\end{array}$ & $\begin{array}{r}53 \\
41.4 \\
7.6\end{array}$ & $\begin{array}{l}14 \\
10.9 \\
2.0\end{array}$ & $\begin{array}{l}13 \\
10.2 \\
1.9\end{array}$ & $\begin{array}{l}19 \\
14.8 \\
2.7\end{array}$ & $\begin{array}{r}29 \\
22.7 \\
4.1\end{array}$ & $\begin{array}{l}128 \\
100.0 \\
18.3\end{array}$ \\
\hline 6 th grade & $\begin{array}{l}\mathrm{N} \\
\% \text { in grade } \\
\% \text { in total }\end{array}$ & $\begin{array}{r}35 \\
33.0 \\
5.0\end{array}$ & $\begin{array}{l}8 \\
7.5 \\
1.1\end{array}$ & $\begin{array}{l}16 \\
15.1 \\
2.3\end{array}$ & \begin{tabular}{r}
\multicolumn{1}{c}{31} \\
29.2 \\
4.4
\end{tabular} & $\begin{array}{l}16 \\
15.1 \\
2.3\end{array}$ & $\begin{array}{l}106 \\
100.0 \\
15.1\end{array}$ \\
\hline Total & $\begin{array}{l}\mathrm{N} \\
\% \text { in grade } \\
\% \text { in total }\end{array}$ & $\begin{array}{c}236 \\
33.7 \\
33.7\end{array}$ & $\begin{array}{c}108 \\
15.4 \\
15.4\end{array}$ & $\begin{array}{c}69 \\
9.9 \\
9.9\end{array}$ & $\begin{array}{c}103 \\
14.7 \\
14.7\end{array}$ & $\begin{array}{l}184 \\
26.3 \\
26.3\end{array}$ & $\begin{array}{l}700 \\
100.0 \\
100.0\end{array}$ \\
\hline
\end{tabular}

\section{검사자 선정 및 훈련}

LSSC 표준화 자료 수집에는 예비검사에 참여하여 검사 내용이 나 실시 절차를 잘 알고 있으며, 검사 실시에 숙달되어 있는 대학원 생과 학부생을 검사자로 활용하였다. 검사자로 선정된 학생들에게 는 검사 실시 전에 검사의 내용과 실시 절차에 대해 사전 교육과 훈 련을 실시하였다. 광주와 충청 지역의 경우에는 아동 비율을 조절 하기 위한 추가 검사에서 해당 지역 대학에서 언어병리학을 전공하 는 대학원생 및 대학생들을 검사자로 활용하였으며, 이 경우 연구 자 중 1 인이 직접 해당 대학을 방문하여 검사자 훈련을 실시하였다.

\section{검사 실시 및 채점}

표준화 검사는 아동들이 교육을 받고 있는 학교나 학원, 혹은 복 지관 등의 빈 교실이나 특별활동실 등 독립적으로 검사를 실시할 수 있는 장소를 이용하였으며, 검사 장소가 여의치 않은 경우에는 아동의 집을 개별적으로 방문하여 검사를 실시하거나 대학 내의 임상실습실을 활용하였다.

검사결과는 검사를 실시하는 즉시 그 자리에서 기록하였으며, 검사 후 2 주일 이내에 채점에 대해 훈련받은 대학원생들이 1 차로 채점을 하였고, 다시 한 달 이내에 채점 내용을 재검토하여 최소 2 회 이상의 채점을 거치도록 하였다.

\section{채점 및 결과 코딩}

검사 결과는 예비검사 과정을 통해서 정리된 채점 지표에 따라 채점을 하였다. 모든 아동의 검사 결과는 2 회 이상의 채점 과정을 거쳐 채점하였다. 먼저 검사 실시 후 검사자가 바로 가채점하도록 하였으며, 검사자에 의해 가채점된 내용을 연구자가 함께 참여한 상황에서 LSSC의 채점에 대해 훈련받은 석사과정생 3 인이 2 회 이 상 다시 채점하고 검토하였다. 이 과정에서 채점 지표도 계속 수정 보완하였다.

채점된 결과는 통계 분석을 위해 엑셀과 SPSS 통계 프로그램에 코딩하였다. 결과 코딩에는 훈련받은 석사과정생 2 명이 참여하였으 며, 두 사람이 함께 작업하여 코딩 오류를 최소화하였다. 코딩된 결 과도 2 회 이상 검토를 통해 오류가 없도록 하였다.

\section{검사의 타당도 및 신뢰도 분석과 규준 작성}

먼저 검사의 타당도는 LSSC와 REVT와의 공인타당도를 측정하 였으며, 구인타당도를 살펴보기 위한 방법으로 모든 하위검사와 언 어지수들 간의 상관 분석을 실시하여 측정하였다. 신뢰도는 검사의 Chronbach $\alpha$ 를 통한 내적일치도와 Spearman-Brown 공식에 의한 반분신뢰도, 그리고 Pearson correlation을 통한 검사-재검사 신뢰 도의 방법으로 측정하였다.

규준은 하위검사들마다 문항 수가 다르므로 먼저 각 하위검사 별 원점수를 표준점수(환산점수)로 환산하고, 각 환산점수를 합산 
한 값을 이용하여 전체 언어지수와 언어양식별 지수(수용언어지 수, 표현언어지수), 언어영역별 지수(의미, 문법, 화용, 청각기억)를 산출하였다.

\section{연구 결과}

\section{타당도}

공인타당도

REVT와의 상관분석 결과

공인타당도를 검정하기 위하여 LSSC와 REVT-E/-R과 상관분석 을 실시한 결과는 Table 2 와 같다. LSSC 전체점수와 REVT-R과 REVT-E와는 각각.888과 .877로 모두 $p<.001$ 수준에서 유의한 상 관을 보였다. 또한 각 하위검사와의 상관계수도 문법판단과 문장 따라말하기 검사가 REVT-E와 각각 .570과 .582의 보통 수준의 상
관계수를 보인 것을 제외하고는 모두 $p<.001$ 수준에서 .60-.90 사 이의 높은 상관을 보였다.

\section{구인타당도: 하위 검사와 전체점수 간 상관}

검사 전체점수와 하위검사들 간의 상관분석은 구인타당도를 검 정하는 하나의 방법이 될 수 있다(Sung, 1998). 구인타당도를 검정 하기 위해 LSSC 전체점수와 하위검사 간의 상관관계 분석을 실시 한 결과는 Table 3 과 같다. 모든 하위검사들 간에 $p<.001$ 수준에서 유의한 정적상관이 있었으며, 각 하위검사들과 전체 언어지수(LQ) 간에도 $p<.001$ 수준에서 .60에서 .80 이상의 높은 상관을 보였다. 또한 수용언어 하위검사들은 수용언어지수(RLQ)와 $p<.001$ 수준 에서 .68에서 .81의 높은 상관을 보였으며, 표현언어 하위검사들도 표현언어지수(ELQ)와 모두 $p<.001$ 수준에서 .80 이상의 매우 높 은 상관을 보였다.

Table 2. Correlations between the LSSC and the REVT $(N=70)$

\begin{tabular}{cccccccccccccc}
\hline & 1 & 2 & 3 & 4 & 5 & 6 & 7 & 8 & 9 & 10 & 11 & 12 \\
\hline REVT-R & $.674^{* * *}$ & $.806^{* * *}$ & $.824^{* * *}$ & $.780^{* * *}$ & $.607^{* * *}$ & $.714^{* * *}$ & $.614^{* * *}$ & $.759^{* * *}$ & $.762^{* * *}$ & $.716^{* * *}$ & $.625^{* * *}$ & $.888^{* * *}$ \\
REVT-E & $.691^{* * *}$ & $.818^{* * *}$ & $.788^{* * *}$ & $.779^{* * *}$ & $.600^{* * *}$ & $.767^{* * *}$ & $.570^{* * *}$ & $.679^{* * *}$ & $.760^{* * *}$ & $.720^{* * *}$ & $.582^{* * *}$ & $.877^{* * *}$ \\
\hline
\end{tabular}

LSSC=Language Scale for School-age Children; REVT-R=Receptive \& Expressive Vocabulary Test-receptive; REVE-E=Receptive \& Expressive Vocabulary Test-expressive; 1 = superordinate comprehension; 2 = superordinate expression; 3 = antonym expression; $4=$ synonym expression; $5=$ sentence comprehension; $6=$ figurative sentence comprehension; 7 = grammatical error judgement; $8=$ grammatical error revision; $9=$ combining sentences; $10=$ understanding spoken paragraph; $11=$ sentence repetition; $12=$ total. ${ }^{* * *} p<.001$.

Table 3. Correlations among subtests and language index scores of the LSSC

\begin{tabular}{|c|c|c|c|c|c|c|c|c|c|c|c|c|c|c|c|}
\hline & SOC & SC & FSC & GEJ & USP & SOE & $\mathrm{AE}$ & SE & GER & CS & SR & RLO & ELO & LO & Sm0 \\
\hline \multicolumn{16}{|l|}{ SOC } \\
\hline SC & .36 & & & & & & & & & & & & & & \\
\hline FSC & .34 & .35 & & & & & & & & & & & & & \\
\hline GEJ & .46 & .38 & .37 & & & & & & & & & & & & \\
\hline USP & .52 & .44 & .47 & .52 & & & & & & & & & & & \\
\hline SOE & .59 & .37 & .40 & .47 & .58 & & & & & & & & & & \\
\hline $\mathrm{AE}$ & .52 & .41 & .45 & .50 & .58 & .62 & & & & & & & & & \\
\hline SE & .46 & .34 & .42 & .46 & .55 & .58 & .66 & & & & & & & & \\
\hline GER & .47 & .44 & .44 & .81 & .59 & .56 & .57 & .52 & & & & & & & \\
\hline CS & .45 & .43 & .46 & .54 & .54 & .55 & .58 & .52 & .61 & & & & & & \\
\hline SR & .46 & .41 & .43 & .50 & .52 & .49 & .55 & .49 & .56 & .62 & & & & & \\
\hline RLO & .73 & .68 & .69 & .74 & .81 & .66 & .67 & .61 & .75 & .66 & .63 & & & & \\
\hline ELO & .61 & .49 & .53 & .68 & .70 & .81 & .84 & .82 & .80 & .80 & .67 & .82 & & & \\
\hline LO & .70 & .60 & .63 & .74 & .78 & .77 & .80 & .76 & .81 & .77 & .68 & .95 & .96 & & \\
\hline Sm0 & .74 & .45 & .64 & .58 & .69 & .79 & .81 & .81 & .65 & .65 & .62 & .85 & .91 & .93 & \\
\hline Sy0 & .54 & .69 & .50 & .84 & .65 & .61 & .64 & .57 & .89 & .81 & .65 & .88 & .86 & .91 & .72 \\
\hline
\end{tabular}

Significant level of all correlation coefficients is $p<.001$.

SOC = superordinate comprehension; $\mathrm{SC}=$ sentence comprehension; $\mathrm{FSC}=$ figurative sentence comprehension; $\mathrm{GEJ}=$ grammatical error judgement; USP= understanding spoken paragraph; $\mathrm{SOE}=$ superordinate expression; $\mathrm{AE}=$ antonym expression; $\mathrm{SE}=$ synonym expression; $\mathrm{GER}=$ grammatical error revision; $\mathrm{CS}=$ combining sentences; $\mathrm{SR}=$ sentence repetition; $R L Q=$ receptive language quotient; $E L Q=$ expressive language quotient; $L Q=$ language quotient; $S m Q=$ semantics quotient; $S y 0=$ syntax quotient. 
Table 4. Mean performance and difference of the LSSC and composite scores by grade

\begin{tabular}{|c|c|c|c|c|c|c|c|c|}
\hline & $\begin{array}{l}\text { 1st grade } \\
(\mathrm{N}=110)\end{array}$ & $\begin{array}{l}\text { 2nd grade } \\
(\mathrm{N}=109)\end{array}$ & $\begin{array}{l}\text { 3rd grade } \\
(\mathrm{N}=123)\end{array}$ & $\begin{array}{l}\text { 4th grade } \\
(\mathrm{N}=124)\end{array}$ & $\begin{array}{l}5 \text { th grade } \\
(\mathrm{N}=128)\end{array}$ & $\begin{array}{l}\text { 6th grade } \\
(\mathrm{N}=106)\end{array}$ & $F$ & Tukey post-hoc \\
\hline \multicolumn{9}{|l|}{ Receptive language } \\
\hline SOC & 13.86 & 15.93 & 18.17 & 18.36 & 20.23 & 20.64 & $84.292^{* * *}$ & $1<2<3,4<5,6$ \\
\hline SC & 29.66 & 30.90 & 32.33 & 32.94 & 33.55 & 33.80 & $64.611^{* * *}$ & $1<2<3,4<5,6$ \\
\hline FSC & 7.41 & 9.86 & 11.55 & 13.09 & 15.25 & 16.73 & $66.611^{* * *}$ & $1<2<3,4<5,6$ \\
\hline GEJ & 23.32 & 27.99 & 29.69 & 29.86 & 32.06 & 32.69 & $54.764^{* * *}$ & $1<2,3<4<5,6$ \\
\hline USP & 12.17 & 14.74 & 17.77 & 17.14 & 20.14 & 20.91 & $42.248^{* * *}$ & $1<2<3,4<5,6$ \\
\hline \multicolumn{9}{|l|}{ Expressive language } \\
\hline SOE & 6.10 & 7.99 & 10.49 & 12.35 & 14.73 & 15.80 & $121.269^{* * *}$ & $1<2<3<4<5,6$ \\
\hline $\mathrm{AE}$ & 7.62 & 9.80 & 12.24 & 13.10 & 15.6 & 16.41 & $121.994^{* * *}$ & $1<2<3,4<5,6$ \\
\hline SE & 1.99 & 3.28 & 5.244 & 6.33 & 9.86 & 11.31 & $128.863^{* * *}$ & $1,2<3,4<5<6$ \\
\hline GER & 16.50 & 21.70 & 23.62 & 24.35 & 27.18 & 28.26 & $74.884^{* * *}$ & $1<2,3<4<5,6$ \\
\hline CS & 7.56 & 11.11 & 14.02 & 16.51 & 20.41 & 21.96 & $95.579^{* * *}$ & $1<2<3<4<5,6$ \\
\hline \multicolumn{9}{|l|}{ Supplement } \\
\hline SR & 49.16 & 52.20 & 54.55 & 55.68 & 60.53 & 60.53 & $24.544^{* * *}$ & $1,2<3,4<5,6$ \\
\hline Total & 126.20 & 153.29 & 175.14 & 183.98 & 208.98 & 218.51 & $139.726^{* * *}$ & $1<2<3,4<5,6$ \\
\hline Receptive language & 86.43 & 99.42 & 109.52 & 111.33 & 121.23 & 124.76 & $105.096^{* * *}$ & $1<2<3,4<5,6$ \\
\hline Expressive language & 39.77 & 53.87 & 65.62 & 72.64 & 87.76 & 93.75 & $151.887^{* * *}$ & $1<2<3<4<5<6$ \\
\hline Semantics & 36.98 & 46.85 & 57.70 & 63.19 & 75.65 & 80.89 & $161.856^{* * *}$ & $1<2<3<4<5,6$ \\
\hline Syntax & 77.05 & 91.70 & 99.67 & 103.65 & 113.20 & 116.72 & $105.447^{* * *}$ & $1<2<3,4<5,6$ \\
\hline
\end{tabular}

SOC = superordinate comprehension; $\mathrm{SC}=$ sentence comprehension; $\mathrm{FSC}=$ figurative sentence comprehension; GEJ = grammatical error judgement; USP= understanding spoken paragraph; $\mathrm{SOE}=$ superordinate expression; $\mathrm{AE}=$ antonym expression; $\mathrm{SE}=$ synonym expression; $\mathrm{GER}=$ grammatical error revision; $\mathrm{CS}=$ combining sentences; $\mathrm{SR}=$ sentence repetition.

${ }^{* * *} p<.001$.

Table 5. Internal consistency of item by grade: Chronbach $\alpha$

\begin{tabular}{|c|c|c|c|c|c|c|c|}
\hline Subtests & 1st grade & 2nd grade & 3rd grade & 4th grade & 5th grade & 6 th grade & Total \\
\hline \multicolumn{8}{|c|}{ Receptive language } \\
\hline SOC & .575 & .665 & .645 & .772 & .638 & .699 & .788 \\
\hline SC & .561 & .556 & .431 & .631 & .384 & .226 & .841 \\
\hline FSC & .498 & .556 & .813 & .852 & .855 & .859 & .872 \\
\hline GEJ & .906 & .900 & .802 & .832 & .691 & .680 & .896 \\
\hline USP & .765 & .687 & .814 & .872 & .822 & .822 & $.809 / .854$ \\
\hline \multicolumn{8}{|c|}{ Expressive language } \\
\hline SOE & .677 & .729 & .725 & .785 & .726 & .746 & .853 \\
\hline $\mathrm{AE}$ & .733 & .738 & .676 & .793 & .619 & .693 & .752 \\
\hline SE & .683 & .673 & .797 & .788 & .745 & .763 & .867 \\
\hline GER & .839 & .857 & .788 & .827 & .743 & .702 & .873 \\
\hline CS & .877 & .876 & .886 & .900 & .897 & .862 & .930 \\
\hline \multicolumn{8}{|c|}{ Supplement } \\
\hline SR & .901 & .857 & .875 & .896 & .832 & .850 & .893 \\
\hline Total & .952 & .959 & .961 & .970 & .959 & .956 & $.972 / .972$ \\
\hline
\end{tabular}

SOC= superordinate comprehension; $\mathrm{SC}=$ sentence comprehension; FSC = figurative sentence comprehension; GEJ = grammatical error judgement; USP: understanding spoken paragraph; $\mathrm{SOE}=$ superordinate expression; $\mathrm{AE}=$ antonym expression; $\mathrm{SE}=$ synonym expression; $\mathrm{GER}=$ grammatical error revision; $\mathrm{CS}=\mathrm{combining}$ sentences, $\mathrm{SR}=$ sentence repetition.

\section{학년에 따른 차이 분석}

LSSC가 학년 간의 차이를 반영하는가를 살펴보기 위하여 전체 점수 및 각 하위검사에 대한 일원변량분석과 Tukey 사후검정을 실 시하였다. Table 4 에 제시된 결과와 같이, 모든 언어지수들과 하위 검사들은 학년이 높아짐에 따라 점수가 증가되었으며, 학년에 따른
유의한 차이를 나타냈다. 사후분석 결과, 전체 언어지수(LQ)와 수 용언어지수(RLQ), 표현언어지수(ELQ)는 3학년과 4학년, 5 학년과 6학년 간을 제외한 모든 학년 간에 유의한 차이를 보였다. 각 하위 검사들도 약간의 차이는 있으나 대체로 학년 간에 유의한 차이를 보였다. 
Table 6. Split-half reliability

\begin{tabular}{|c|c|c|c|c|c|c|c|}
\hline Subtests & 1st grade & 2nd grade & 3rd grade & 4th grade & 5th grade & 6 th grade & Total \\
\hline \multicolumn{8}{|c|}{ Receptive language } \\
\hline SOC & .245 & .495 & .499 & .725 & .455 & .628 & .669 \\
\hline SC & .423 & .583 & .327 & .574 & .348 & .489 & .604 \\
\hline FSC & .435 & .728 & .802 & .848 & .862 & .861 & .863 \\
\hline GEJ & .858 & .858 & .759 & .796 & .663 & .700 & .865 \\
\hline USP & .658 & .593 & .787 & .804 & .804 & .782 & .754 \\
\hline \multicolumn{8}{|c|}{ Expressive language } \\
\hline SOE & .582 & .666 & .734 & .733 & .722 & .789 & .835 \\
\hline $\mathrm{AE}$ & .771 & .723 & .650 & .754 & .610 & .610 & .807 \\
\hline SE & .599 & .585 & .771 & .734 & .715 & .736 & .838 \\
\hline GER & .801 & .794 & .748 & .813 & .758 & .691 & .855 \\
\hline CS & .849 & .845 & .782 & .746 & .754 & .751 & .842 \\
\hline \multicolumn{8}{|c|}{ Supplement } \\
\hline SR & .897 & .852 & .856 & .871 & .788 & .854 & .879 \\
\hline Total & .833 & .870 & .917 & .917 & .905 & .908 & .910 \\
\hline
\end{tabular}

SOC= superordinate comprehension; $\mathrm{SC}$ = sentence comprehension; $\mathrm{FSC}=$ figurative sentence comprehension; $\mathrm{GEJ}$ = grammatical error judgement; USP= understanding spoken paragraph; $\mathrm{SOE}=$ superordinate expression; $\mathrm{AE}=$ antonym expression; $\mathrm{SE}=$ synonym expression; $\mathrm{GER}=$ grammatical error revision; $\mathrm{CS}=$ combining sentences; $\mathrm{SR}=$ sentence repetition.

Table 7. Test-retest reliability

\begin{tabular}{lccl}
\hline Subtests & Test & Retest & Total \\
\hline Receptive language & & & \\
SOC & $19.00(2.902)$ & $19.60(3.470)$ & $.758^{* * *}$ \\
SC & $32.40(2.371)$ & $33.30(1.838)$ & $.478^{*}$ \\
FSC & $12.25(5.581)$ & $14.90(6.307)$ & $.910^{* *}$ \\
GEJ & $31.40(3.515)$ & $30.55(5.114)$ & $.763^{* * *}$ \\
USP & $18.85(6.201)$ & $20.90(6.189)$ & $.890^{* * *}$ \\
Expressive language & & & \\
SOE & $11.80(5.337)$ & $12.80(4.538)$ & $.939^{* * *}$ \\
AE & $14.35(4.368)$ & $15.25(3.726)$ & $.935^{* * *}$ \\
SE & $7.60(4.849)$ & $8.60(5.567)$ & $.924^{* * *}$ \\
GER & $26.25(4.191)$ & $26.55(5.083)$ & $.715^{* *}$ \\
CS & $18.25(7.217)$ & $19.15(6.706)$ & $.947^{* * *}$ \\
Supplement & & & \\
SR & $58.25(11.688)$ & $62.65(7.066)$ & $.902^{* * *}$ \\
Total & $192.15(40.786)$ & $201.60(41.223)$ & $.968^{* * *}$ \\
\hline
\end{tabular}

Values are presented as mean (SD).

$\mathrm{SOC}=$ superordinate comprehension; $\mathrm{SC}=$ sentence comprehension; $\mathrm{FSC}=$ figurative sentence comprehension; GEJ = grammatical error judgement; USP = understanding spoken paragraph; $\mathrm{SOE}=$ superordinate expression; $\mathrm{AE}=$ antonym expression; $\mathrm{SE}=$ synonym expression; $\mathrm{GER}=$ grammatical error revision; $\mathrm{CS}=$ combining sentences; $\mathrm{SR}=$ sentence repetition.

${ }^{*} p<.05,{ }^{* *} p<.01,{ }^{* * *} p<.001$

\section{신뢰도}

검사내적일치도

검사의 신뢰도는 내적일치도를 측정하는 Chronbach $\alpha$ 로 측정하 였다(Table 5). 문항의 내적일관성 신뢰도는 문항 하나하나를 하나 의 검사로 간주하여 문항들 간의 유사성 혹은 측정의 일관성을 검정 하는 방법이다(Sung, 1995). 전체 문항의 내적일치도는 .972로 매우 높은 내적일치도를 보였으며, 각 학년별로도.952에서.970으로 매우
높은 내적일치도롤 보였다. 각 학년별로도 하위검사별 내적일치도 도 일부 하위검사를 제외하고는.60-.94로 높은 신뢰도를 보였다.

\section{반분신뢰도}

반분신뢰도는 각 하위항목별 검사 문항을 대등하게 두 개로 구 분하고 각 문항 간의 상관계수를 구하여 신뢰도를 측정하는 방법 이다(Sung, 1995). LSSC는 하위검사와 학년마다 측정치에 차이가 있으나 전체 점수의 Spearman-Brown 계수가 .910으로 매우 높은 측정치를 보였으며, 하위검사의 전체 측정치도 일부 하위검사를 제 외하고는 Spearman-Brown 계수가.60 이상으로 신뢰도가 높은 것 으로 측정되었다(Table 6).

\section{검사-재검사 신뢰도}

검사의 시간적 안정성을 평가하기 위하여 검사-재검사 신뢰도를 측정하였다. 검사-재검사 신뢰도는 총 20 명의 아동을 대상으로 측 정하였으며, 1 차 검사 후 약 1 주일에서 2 주일 사이에 2 차 검사를 실 시하였다. 전체 점수의 재검사 신뢰도는 .968 로 매우 높은 측정치를 보였으며, 하위 검사의 전체 측정치도 대체로 상위개념 이해와 구 문이해 검사를 제외하고는 모두 .70 이상의 매우 높은 재검사 신뢰 도를 보였다(Table 7).

\section{검사의 규준 작성}

\section{하위검사 환산점수의 산출}

각 하위검사의 문항 수가 다르므로 하위검사 점수를 표준화하기 위하여 원점수를 평균이 10 , 표준편차가 3 인 값으로 환산하도록 하 
였다. 환산점수가 7-13은 \pm 1 표준편차 이내에, 4-7과 14-16은 각각 -2 -1 표준편차와 +1 +2 표준편차에 해당한다.

\section{언어지수 산출}

하위검사의 환산점수들을 합산하여 언어지수를 산출하도록 하 였다. LSSC에서 산출하는 각 언어지수는 평균이 100이고 표준편 차가 15 인 표준점수로, 평균값은 해당 학년에서의 평균적인 아동 수행 수준을 대표해주는 수치라 할 수 있다. 이론적 분포에 기초하 여 평균을 중심으로 \pm 1 표준편차 이내에 해당하는 85-114에 전체 $66 \%, \pm 2$ 표준편차 내에는 $95 \%$ 해당하도록 통계 처리하였다. 언어 지수에 대한 해석을 용이하게 하기 위하여 K-WISC-III나 KISE$\mathrm{BAAT}$ 와 같은 아동용 지능검사나 학력검사에서 사용하는 분류 기준에 따라 언어지수가 69 이하로 평균에서 -2 표준편차 이하에 속하는 경우는 언어능력이 많이 부족한 상태이며, 언어지수가 7084 사이로 -1 표준편차 이하인 경우에는 약간 부족한 상태로 해석 하게 하였다. 반대로 언어지수가 115-129 사이로 +1 표준편차 이상 인 경우는 우수한 수준이며, 언어지수 130 이상인 경우는 매우 우 수한 수준으로 해석 지침을 제시하였다.

\section{백분위 수의 산출}

백분위 수는 학년 집단 내에서 대상 아동의 위치가 상위 몇 퍼센 트에 해당하는가를 나타내주며, 언어지수와 마찬가지로 대상 아동 이 차지하는 상대적 위치에 대한 정보를 제공해준다. 백분위 수는 대상 아동의 아래에 해당하는 아동들의 비율을 나타내 주는 것으 로 수가 높을수록 해당 집단 내에서 상위에 해당된다. LSSC는 점 수를 표준점수화하여 언어지수가 69 이하로 평균에서 -2 표준편차 이하에 속하는 경우는 전체의 하위 $2.3 \%$ (2.3\% ile) 이하에 해당하 도록 하였으며, 언어지수가 70-84 사이로 -1 표준편차 이하인 경우 에는 전체의 하위 $13.6 \%$ (15.9\%ile) 이하에 해당하도록 하였다. 반 대로 언어지수가 115-129 사이로 +1 표준편차 이상인 경우는 상위 $13.6 \%$ (86.4\%ile)에 해당하여 우수한 수준이며, 언어지수 130 이상 인 경우는 상위 $2.3 \%$ (97.7\%ile) 이상에 해당하도록 하였다.

\section{논의 및 결론}

본 연구는 학령기 아동의 언어능력을 진단하고 중재가 필요한 아동을 확인하는 데 활용할 수 있는 표준화 검사 개발을 목적으로 하였다. 검사는 문헌연구를 통한 검사 개발 및 전문가 내용타당도 검정, 2 차에 걸친 예비검사를 통한 문항 선별과 검사 타당도 검정, 그리고 마지막으로 표준화 검사의 과정을 거쳐 개발되었다.
먼저 검사도구는 관련 문헌 연구와 2 회에 걸친 예비검사를 통해 검사를 개발하였다. 검사를 개발할 때에는 수용언어와 표현언어 양식(modality)이 모두 평가될 수 있도록 구성하였으며, 문법, 의미, 화용과같은 언어 영역이 포함되도록 고려하였다. 평가 절차는 TOLDI (Hammill \& Newcomer, 1982)나 CELF-4 (Semel et al., 2003), 또 는 WLPB-R (Woodcock, 1991)과 같이 이미 학령기 아동의 언어 검 사로 타당도가 보고된 검사를 참조로 하여 결정하였으며, 검사 문 항은 학령기 언어발달 연구 자료들과 초등학교 국어 교과서와 초 등학생들을 대상으로 출판된 읽기 자료들을 분석하여 검사에 사 용할 어휘와 구문 등을 결정하였다. 이러한 과정을 통해 LSSC가 이 론적 타당성을 확보하고자 하였다.

또한 신뢰도와 타당도가 높은 검사를 개발하기 위해 2 회에 걸쳐 각각 178 명과 182 명의 초등학생을 대상으로 예비검사를 실시하고 문항분석과 신뢰도 및 타당도 분석을 하였다. 1 차 예비검사에서는 문헌연구를 통해 6개의 하위검사와 각 하위검사별로 1.5-2배수로 개발된 예비문항에 대해 BayesiAn 문항반응이론에 근거한 문항 분석을 실시하고 변별도가 . 30 이하로 낮은 변별도 문항은 제외하 였다. 개발된 검사에 대해서 실시한 타당도와 신뢰도 분석에서는 개발된 검사의 전체점수와 각 하위검사 점수들 간의 상관계수가 모 두 .80 이상이었으며, K-WISC-III의 언어성 검사의 전체점수 및 하 위검사 간에도 상관계수가 .909로 높은 구인타당도와 공인타당도 를 보였다. 내적일치도를 측정하기 위하여 Chronbach $\alpha$ 를 측정한 결과 전체 문항은 .98 , 각 하위검사는 .82-.94로 매우 높은 신뢰도를 나타냈다. 2 차 예비검사에서는 1 차에서 개발된 검사가 표현언어 양 식에 치중되어 이를 보완하고자 5 개의 하위검사를 추가하였다. 추가 된 검사에 대해 1 차 검사와마찬가지로 BayesiAn 방법으로 문항 분 석을 실시하여 변별도 높은 문항을 선별한 후 1 차 예비검사에서 개 발된 검사와의 공인타당도와 Chronbach $\alpha$ 로 신뢰도를 측정한 결 과 각각 $r=.50-.76$ 과 $\alpha=.85-.88$ 로 높은 타당도와 신뢰도를 보였다.

표준화 연구에서는 무엇보다 표본의 대표성이 중요하다. Maxwell과 Satake (2006)는 표본의 대표성을 확보하기 위해서는 충분 한 수를 확보해야 하며, 대상이 특정 지역이나 계층으로 편향되지 않도록 하여야 한다고 하였다. LSSC는 각 학년별로 최소 100 명 이 상을 대상으로 포함되도록 하였으며, 각 학년별로 106명에서 128 명 까지 총 700명을 대상으로 하여 충분한 대상을 확보하였다. 또한 표 본이 특정 지역에 집중되지 않도록 아동 표집 시 전국을 서울, 경상 (부산, 대구광역시 포함), 전라(광주광역시 포함), 충청, 강원·경기 의 5 대 권역으로 구분한 후, 통계청에서 보고한 각 지역별 아동 인구 분포를 고려하여 서울 $25 \%-30 \%$, 경상 $20 \%$ 내외, 강원·경기 $25 \%$ 내외, 충청 $10 \%-15 \%$, 전라 $10 \%$ 내외로 설정하여 군집표집법과 편 
의표집법을 통해 표집하였으며, 각 권역별 자료에는 최소 3 곳 이상 의 지역이 포함되도록 하여 자료가 특정 지역에 편향되지 않도록 하였다. 최종적으로 표집된 아동 분포는 학년마다 차이는 있으나 서 울 $33.7 \%$, 경상 $15.4 \%$, 전라 $9.9 \%$, 충청 $14.7 \%$, 강원.경기 $26.3 \%$ 로 대체로 전국적으로 고르게 표집되었다. 또한, 일부 조사되지 않은 아동의 자료가 포함되어 통계 자료는 보고하지 못하였으나 부모의 교육 수준을 부모 모두 고졸 이상으로 하여 통제하고자 노력하였 으며, 이 역시 표본의 대표성을 확보하는 데 기여가 되었다.

표본의 대표성 확보와 더불어 신뢰도 확보를 위해 아동 반응을 정리하고 한국어 문법책과 사전 내용을 기반으로 채점 기준을 마 련하였으며, 문법책이나 사전으로 확실하지 않은 일부 반응에 대해 서는 국어학자의 자문을 얻어 채점 기준의 신뢰도를 높이고자 하 였다. 또한 마련된 지침을 기반으로 검사 자료를 채점할 때에도 두 사람 이상이 2 회 이상 재검토하였으며, 통계 분석을 위한 자료 코딩 시에도 두 사람 이상이 2 회 이상 점검하여 오류가 없도록 하였다.

표준화 검사를 통해 얻어진 검사의 타당도와 신뢰도는 각각 3 가 지 이상의 방법을 통하여 검증하였다(Haynes \& Pindzola, 2008). 먼저 타당도는 REVT-R/-E (Kim et al., 2009)와의 공인타당도와 LSSC의 각 언어지수와 하위검사들 간의 상관분석을 통한 구인타 당도, 그리고 학년에 따른 차이검증 세 가지로 진행하였다. 먼저 LSSC와 REVT-R/-E는 LSSC와 각각 $r=.888, r=.877$ 의 상관관계 를 보여 매우 높은 공인타당도를 보였다. LSSC 모든 하위검사들과 도 REVT-R은 .60-.90 사이, REVT-E는 .57-.90 사이의 높은 상관을 보였다. 특히 LSSC 하위 검사 중에서 상위어 표현, 반의어 표현, 동 의어 표현과 같은 어휘 검사와 $r=.78-82$ 의 높은 상관을 보여 검사 타당도를 입증하였다. 구인타당도는 LSSC 언어지수와 각 하위검사 들 간의 상관분석을 통해 측정하였는데, 모든 하위검사가 전체 점 수와.60-81 사이의 높은 타당도를 보였다. 특히 수용언어를 측정하 는 하위검사들은 수용언어지수와 표현언어를 측정하는 하위검사 들은 표현언어지수와 더 높은 상관관계를 나타냈는데 이는 LSSC 가 수렴타당도 및 판별타당도를 어느 정도 갖추었음을 보여 준다.

타당도를 검정하기 위한 한 방법으로 학년에 따른 차이 검정을 실시하였는데, 전체 언어점수는 물론 수용과 표현, 문법과 의미, 그 리고 하위검사 모두에서 학년에 따른 유의한 차이를 나타내 LSSC 가 학년 증가에 따른 언어발달 정도를 평가하는 데 타당한 검사임 을 입증하였다. Tukey 사후분석을 통해 전체 언어지수, 수용 및 표 현언어 지수, 문법과 의미지수, 그리고 각 하위검사 별로 각 학년 간 의 차이를 검정한 결과에서는, 표현언어지수와 의미지수, 그리고 하위검사 중 복문 만들기 검사는 5 학년과 6 학년 사이를 제외한 모 든 학년 사이에서, 전체 언어지수와 수용언어지수, 문법지수, 그리
고 복문 만들기 검사를 제외한 모든 하위검사는 3 학년과 4 학년, 5 학년과 6학년 사이를 제외하고는 모든 학년 사이에서 유의한 차이 를 보였다(Table 4). 이러한 결과는 LSSC의 표현언어지수나 의미영 역 지수가 학년 차이를 더 민감하게 반영함을 시사하며, 대체로 학 령기 아동의 언어 능력이 고학년으로 진행함에 따라 차이가 감소 함을 보여 준다.

신뢰도도 Chronbach $\alpha$ 를 통한 검사내적일치도, 반분신뢰도, 검 사-재검사 신뢰도의 세 가지 방법을 통해 검정하였다. 언어검사 전 체 문항의 내적일치도는 .972로 매우 높은 신뢰도를 보였으며, 하위 검사별 내적일치도도 .752-.930의 매우 높은 일치도를 보였다. 학년 별로도 전체 점수 내적일치도가.952-.970으로 매우 높았다. 반분신 뢰도 검사에서는 전체 점수 신뢰도가.910으로 매우 높은 신뢰도를 보였으며 학년별로도.833-917로 매우 높은 신뢰도를 보였다. 마지막 으로 검사-재검사 신뢰도 역시 전체 점수에 대한 상관계수가. 968 로 나타나 매우 높은 상관을 보였다.

학년별로 측정한 신뢰도 검사도 대부분 높은 신뢰도를 보고하였 다. 반면, 구문 이해 검사는 Cronbach $\alpha$ 로 측정한 내적일치도나 반 분신뢰도 결과에서 1-6학년을 합한 점수에서는 높은 신뢰도를 보 였으나 각 학년별 결과, 특히 5, 6학년 결과에서는 다른 하위검사에 비해 상대적으로 낮은 신뢰도를 보였다. 이러한 결과는 구문 이해 검사가 다른 검사에 비해 상대적으로 쉬워서 변별도가 낮았던 것 때문으로 보인다. 이러한 점은 LSSC 수정 시 고려하여야 할 것이다.

신뢰도 검정 결과는 LSSC가 타당도와 더불어 신뢰도 역시 매우 높은 검사임을 입증하며, 이러한 높은 신뢰도는 검사 개발 과정에 서부터 선행 문헌에서 신뢰롭고 타당하다고 보고된 평가 절차들로 검사를 구성하고, 아동용 문헌 자료에 기반하여 검사 문항을 결정 하고, 문항반응이론에 기초하여 변별도가 높은 문항을 선정하거나 검사 실시 또는 채점 과정을 엄격하게 관리한 것에 기반한 것으로 보인다.

LSSC는 다음과 같은 점에서 의의를 찾을 수 있다. 첫째, 수용언 어와 표현언어 두 언어양식은 물론 문법, 의미, 화용의 언어영역이 모두 평가될 수 있도록 하였으며, 언어영역별로도 수용과 표현이 균 형 있게 평가될 수 있도록 검사를 구성하였다는 것이다. 이는 특정 언어 양식이나 영역에 편중되지 않고 아동의 전반적인 언어능력을 평가할 수 있게 한다. 또한 각 언어 양식과 영역별로 언어지수를 제 공하여 아동들의 언어적 강약점을 파악할 수 있게 고려함으로써 LSSC가 언어문제를 갖는 아동 판별에는 물론 중재 방향을 결정할 때에도 도움이 될 수 있도록 하였다. 둘째, 대표성 있는 표본을 표집 하고자 노력하였다는 점이다. 표준화 검사에서 표본의 대표성은 무 엇보다 중요하다. 이를 위해 LSSC는 각 학년별로 100 명 이상의 대 
상이 포함되도록 하여 충분한 사례수를 확보하였을 뿐 아니라, 전 국을 5 개 권역으로 구분하여 각 지역별 아동 분포를 고려하여 대상 아동을 표집하여 표본이 특정 지역에 편향되지 않도록 최선의 노력 을 하였다. 셋째, 자료 수집 및 채점의 신뢰도를 높이기 위해 검사와 채점 및 코딩 모든 과정에서 세심한 노력을 기울였다. 검사자 훈련 과 아동 반응 분석을 통한 구체적인 채점 기준 마련, 채점 및 코딩 결과의 반복 체크 등은 검사의 신뢰도를 높이는 데 도움이 되었다. 넷째, 타당도와 신뢰도를 여러 방법으로 검정하였으며, 검정 결과 높은 타당도와 신뢰도를 보고하였다. 문헌 연구를 통한 검사 개발 과정에서부터 전문가 내용타당도 검정, 문항분석, 세심한 표준화 과정은 모두 검사의 타당도와 신뢰도를 높이는 데 기여하였다고 판 단된다. 마지막으로 검사 규준을 전체 언어점수와 언어양식(수용 및 표현), 언어영역(의미, 문법, 화용)별로 언어지수와 백분위 수로 제시하여 또래와의 상대적인 비교가 쉽게 하였다. 특히 언어지수는 웩슬러 아동용 지능검사나 KISE-BATT와 같은 학업성취도 검사 와 유사하게 평균을 100 , 표준편차 15 인 분포에 기초하여 제시함으 로써 동일한 검사를 사용하는 임상가나 교육자들에게 검사결과를 익숙하게 해석할 수 있도록 고려하였다. 또한 검사 하위검사 결과 도 평균 10 , 표준편차 3 인 표준점수로 환산하도록 하여 하위검사별 수행 역시 상대적 평가가 가능하도록 하였다.

검사 개발에서부터 표준화까지 모든 과정을 충실하게 진행하여 타당도와 신뢰도를 갖추고 나아가 임상이나 교육에 활용도가 높은 검사를 개발하고자 노력하였으나, 듣고 이해하기 검사만으로 구성 된 화용이나 담화 영역은 해당 영역의 수행을 평가하기엔 매우 미 흡하다 하겠다. 화용이나 담화는 학령기 아동에게 무엇보다 중요 한 영역이라 할 수 있기 때문에 이는 LSSC의 큰 제한점으로 보인다. 이는 추후 검사의 재표준화 과정에서 수정해야 할 과제로 남긴다.

\section{REFERENCES}

Ha, H. J., \& Lee, Y. (2006). Reading comprehension in elementary school-age children. Presented at the 2006 Annual Conference of the Korean Academy of Speech-Language Pathology and Audiology, 166-171.

Hammill, D. D., \& Newcomer, P. L. (1982). Test of Language Development: Intermediate. Austin, TX: Pro-Ed

Haynes, W. O., \& Pindzola, R. H. (2008). Assessment of school-age and adolescent language disorders. In Diagnosis and evaluation in speech pathology (7th ed.). Boston: Pearson Education.

Jin, Y. S., Kown, Y., \& Lee, Y. (2008). A literature review of language development and language disorders of school-aged children. Korean Journal of
Communication Disorders, 13, 594-620.

Kim, Y. T., Hong, G. H., Kim, K. H., Jang, H. S., \& Lee, J. Y. (2009). Receptive \& Expressive Vocabulary Test (REVT). Seoul: Seoul Community Rehabilitation Center.

Kim, Y. T., Sung, T. J., \& Lee, Y. K. (2003). Preschool Receptive-Expressive Language Scale (PRES). Seoul: Seoul Community Rehabilitation Center.

Ko, Y. K., \& Nam, K. S. (2005). Standard Korean grammar. Seoul: Top Publishing.

Korea Ministry of Culture and Tourism. (1999). Analysis of vocabulary used in elementary school textbook. Seoul: Author.

Kwak, K. C., Park, H. W., \& Kim, C. T. (2001). Korean Wechsler Intelligence Scale for Children-III (K-WISC-III). Seoul: Seoul Special Education Publishing Co.

Lee, C. W. (1994). Study of Korean educational vocabulary. Seoul: Kookak Publishing.

Lee, E. B. (1989). Study of vocabulary used in elementary school textbook. Seoul: National Institute of the Korean Language.

Lee, H. S. (2007). The effect of sentence length and structure on sentence repetition of school-age children with ADHD (Master's thesis). Hallym University, Chuncheon, Korea.

Lee, Y. (2005). Metalinguistic awareness in children with specific language impairment. Speech Sciences, 12, 15-25.

Lee, Y. (2006). A study for the development of language assessment model for Korean school-age children with language disorders: a qualitative inquiry. Korean Journal of Communication Disorders, 11, 30-50.

Lee, Y. (2007). Validity and reliability analyses of the language test for schoolage children. Korean Journal of Communication Disorders, 12, 569-586.

Lee, Y. (2013). Language assessment of school-age children with language disorders. In H. S. Sim (Ed.), Diagnosis and assessment of communication disorders. Seoul: Hakjisa.

Maxwell, D. L., \& Satake, E. (2006). Research and statistical methods in communication sciences and disorders. Boston, MA: Thomson/Delmar Learning.

Newcomer, P. L., \& Hammill, D. D. (2008). TOLD-P 4: Test of Language Development Primary. Austin, TX: Pro-Ed.

Pae, S. Y., Lim, S. S., \& Lee, H. H. (2000). Korean test of problem solving. Seoul: Seoul Community Rehabilitation Center.

Pae, S., Lim, S. S., Lee, J. H., \& Chang, H. S. (2004). Test of Korean Sentence Comprehension. Seoul: Seoul Community Rehabilitation Center.

Park, H. S. (2003). C-RIC. Seoul: Paradise Welfare Foundation.

Paul, R. (2007). Language disorders from infancy through adolescence: assess- 
ment \& intervention (3rd ed.). St. Louis, MO: Mosby.

Semel, E., Wiig, E. H., \& Secord, W. (2003). Clinical Evaluation of Language Fundamentals (4th ed.). San Antonio, TX: Psychological Corporation.

Sung, T. J. (1995). Reliability and validity. Seoul: Yangseowon.

Sung, T. J. (1998). Research methods of education. Seoul: Hakjisa.

Sung, T. J. (2001). Bayesian item analysis program based on statistical method. http://www.evercation.com/.

Wiig, E. H., Semel, E., \& Secord, W. A. (2013). Clinical Evaluation of Language Fundamentals 5th edition (CELF5). Bloomington, MN: Pearson.

Woodcock, R. W. (1991). Woodcock language proficiency battery-revised (WLPB-

R). Itasca, IL; Riverside Publishing. 
Appendix 1. 1차 예비검사 후 수정 및 추가된 하위검사

\begin{tabular}{|c|c|c|c|c|}
\hline $\begin{array}{l}\text { 하위 } \\
\text { 검사 }\end{array}$ & & 문항수 & 검사내용 및 절차 & 비고 \\
\hline \multirow{5}{*}{ 의미 } & 상위 개념 이해 & 24 & $\begin{array}{l}\text { 기본 수준(basic level)에 속하는 어휘 세 개 혹은 네 개를 들려주고 그 중에서 동일 범주에 속하는 } \\
\text { 어휘 두 개를 선택하게 하여 상위 개념 이해를 평가한다. }\end{array}$ & CELF-4 \\
\hline & 상위어 표현 & 24 & 선택한 두 어휘를 포함하는 상위어가 무엇인지를 말하게 하여 상위어 표현을 평가한다. & $\begin{array}{l}\text { 1차 예비검사 후 추가 } \\
\text { CELF-4, TOLD-1 }\end{array}$ \\
\hline & 반의어 표현 & 22 & 어휘를 들려준 후 제시한 어휘의 반의어를 표현하도록 요구한다. & \multirow{2}{*}{ WLPB-R } \\
\hline & 동의어 표현 & 22 & 어휘를 들려준 후 제시한 어휘의 동의어를 표현하도록 요구한다. & \\
\hline & 비유문장 이해 & 23 & $\begin{array}{l}\text { 관용구와 속담이 포함된 문장을 들려주고, } 4 \text { 개의 보기 그림 중에서 해당되는 그림을 지적하게 한 } \\
\text { 다. 의미 중심의 문장 이해력을 측정한다. }\end{array}$ & 1차 예비검사 후 추가 \\
\hline \multirow{4}{*}{ 문법 } & 문법오류 판단 & 35 & $\begin{array}{l}\text { 제시한 문장이 바른 문장인지 혹은 틀린 문장인지를 판단하게 한다. 문법에 대한 이해능력을 측정 } \\
\text { 한다. }\end{array}$ & \multirow{2}{*}{$\begin{array}{l}\text { TOLD-I } \\
\text { Lee (1996), Lee (2005) 참조 }\end{array}$} \\
\hline & 문법오류 수정 & 35 & $\begin{array}{l}\text { 제시한 문장이 틀렸다고 판단한 경우 틀린 부분을 수정하여 정확한 문장으로 산출하게 한다. 문법 } \\
\text { 표현능력을 측정한다. }\end{array}$ & \\
\hline & 구문 이해 & 35 & $\begin{array}{l}\text { 길이와 구조에 따라 난이도를 달리하는 문장을 들려주고, } 4 \text { 개의 보기 그림 중에서 해당되는 그림 } \\
\text { 을 지적하게 한다. 구문 중심의 문장 이해력을 측정한다. }\end{array}$ & $\begin{array}{l}\text { Ha \& Lee (2006) } \\
\text { 1차 예비검사 후 추가 }\end{array}$ \\
\hline & 복문 산출 & 30 & $\begin{array}{l}\text { 2-4개의 문장을 들려준 후 제시한 문장들을 하나의 문장으로 재구성하여 표현하도록 요구한다. } \\
\text { 제시한 문장들을 그 의미에 기초하여 대등절 또는 종속절로 연결된 복문으로 연결하여 산출하는 } \\
\text { 능력을 평가한다. }\end{array}$ & $\begin{array}{l}\text { TOLD-I } \\
\text { CELF }\end{array}$ \\
\hline $\begin{array}{l}\text { 화용 } \\
\text { 담화 }\end{array}$ & 단락 듣기 이해 & 46 & $\begin{array}{l}\text { 5-8개의 문장으로 이루어진 덩이글을 녹음된 테이프로 들려준 후, 각 덩이글과 관련된 질문에 대 } \\
\text { 답하게 한다. 질문은 사실적 질문과 추론적 질문으로 구성하였으며, 검사자가 아동에게 직접 제 } \\
\text { 시한다. }\end{array}$ & $\begin{array}{l}\text { CELF } \\
\text { WLPB-R }\end{array}$ \\
\hline $\begin{array}{l}\text { 청각 } \\
\text { 기억 }\end{array}$ & $\begin{array}{l}\text { 문장 따라 } \\
\text { 말하기 }\end{array}$ & 24 & $\begin{array}{l}\text { 문장 길이와 구조를 각기 달리하여 아동에게 들려주고 제시된 문장을 정확하게 반복하여 산출하 } \\
\text { 게 한다. 청각적 기억력을 측정한다. }\end{array}$ & $\begin{array}{l}\text { 1차 예비검사 후 추가 } \\
\text { Lee H. (2007) 자료 수정 보완 }\end{array}$ \\
\hline
\end{tabular}

TOLD-I=Test of Language Development-Intermediate; CELF=Clinical Evaluation of Language Fundamentals; WLPB-R=Woodcock Language Proficiency Battery-Revised. 


\section{국문초록}

\section{학령기 아동 언어 검사(LSSC) 표준화 연구}

이윤경 ${ }^{1}$ 허현숙 ${ }^{2} \cdot$ 장승민 ${ }^{3}$

'한림대학교 언어청각학부, ${ }^{2}$ 한림대학교 보건대학원 언어병리학과, ${ }^{3}$ 성균관대학교 심리학과

배경 및 목적: 표준화 언어검사는 언어장애 아동을 판별하는 데 필수적이나 아직까지 학령기 아동을 대상으로 개발된 표준화 언어검사 는 매우 부족하다. 따라서 본 연구는 학령기 언어장애 아동을 판별하는 데 활용될 수 있는 표준화 검사 개발을 목적으로 하였다. 방법: 연구는 문헌연구를 통한 검사 구성 및 문항 개발, 1 차 178 명과 2 차 182 명 아동을 대상으로 2 회에 걸친 예비검사 실시 및 검사 타당도 및 문항 분석을 통한 검사수정, 예비 검사를 통해 확정된 '학령기 아동 언어 검사(LSSC)'에 대해 총 700명의 아동을 대상으로 표준화 검사 실시 순서로 진행하였다. 표준화 검사에 대한 타당도는 LSSC와 REVT 및 K-WISC-III 언어성 검사와의 공인타당도와 하위검사와 언어 지수들 간의 상관분석을 통한 구인타당도로 측정하였다. 신뢰도는 검사의 문항 내적일치도와 반분신뢰도, 그리고 검사-재검사 신뢰도 의 방법으로 측정하였다. 결과: LSSC는 REVT-R/-E와 높은 공인타당도를 보였으며, 언어지수와 하위검사간에도 높은 구인타당도를 보 였다. 검사내적일치도와 반분신뢰도, 재검사 신뢰도를 통한 신뢰도 측정 결과도 모두 높은 신뢰도를 나타냈다. 논의 및 결론: 검사 개발 및 표준화 과정에 대해 논의하였다. 본 검사는 학령기 아동의 언어평가와 언어장애를 진단하는 데 활용될 수 있을 것으로 기대된다.

핵심어: 학령기 아동 언어검사, LSSC, 표준화 검사, 신뢰도, 타당도

\section{참고문헌}

고영근, 남기심(2005). 표준국어문법론. 서울: 탑출판사.

곽금주, 박혜원, 김청택(2001). K-WISC-III. 서울: 도서출판 특수교육.

김영태, 성태제, 이윤경(2003). 취학전 아동의 수용언어 및 표현언어 척도(PRES). 서울: 서울장애인종합복지관.

김영태, 홍경훈, 김경희, 장혜성, 이주연(2009). 수용표현어휘력검사(REVT). 서울: 서울장애인종합복지관.

문화관광부(1999). 교과서의 어휘 분석연구-초등학교 교과서를 대상으로. 서울: 문화관광부.

박현숙(2003). C-RIC. 서울: 파라다이스복지재단.

배소영, 임선숙, 이지희(2000). 언어문제해결력검사. 서울: 서울장애인종합복지관.

배소영, 임선숙, 이지희, 장혜성(2004). 구문의미이해력 검사. 서울: 서울장애인종합복지관.

성태제(1995). 타당도와 신뢰도. 서울: 양서원.

성태제(1998). 교육연구방법의 이해. 서울: 학지사.

성태제(2001). Bayesian 통계방법에 의한 검사분석 프로그램.http://www.evercation.com/.

이윤경(2006). 학령기 아동언어장애 진단 및 평가에 관한 질적연구: 진단 및 평가 모형 정립을 위한 기초연구. 언어청각장애연구, 11, 30-50.

이윤경(2007). 학령기 언어검사 도구 개발: 타당도와 신뢰도 분석을 중심으로. 언어청각장애연구, 12, 569-586.

이윤경(2013). 학령기 아동 언어장애의 진단. 심현섭 외, 의사소통장애의 진단과 평가. 서울: 학지사.

이응백(1989). 초등학교 교과서 어휘 연구. 서울: 국어연구원

이충우(1994). 한국어 교육용 어휘 연구. 서울: 국학자료원.

이혜숙(2007). 문장길이와 구조에 따른 초등 저학년 ADHD 아동의 문장 따라말하기 특성. 한림대학교대학원 석사학위논문.

진연선, 권유진, 이윤경(2008). 학령기 언어발달 및 언어장애 문헌연구: 국내·외 언어병리학 관련 학술지를 중심으로. 언어청각장애연구, 13, 594-620. 하혜주, 이윤경(2006). 초등학교 저학년 아동의 읽기이해능력. 2006년도 한국언어청각임상학회 학술대회 논문집, 166-171. 